\title{
Open Government in Authoritarian Regimes
}

\section{Karl O'Connor, Saltanat Janenova and Colin Knox}

\section{(2) OpenEdition}

\section{Journals}

Electronic version

URL: http://journals.openedition.org/irpp/325

DOI: 10.4000/irpp.325

ISSN: 2706-6274

\section{Publisher}

International Public Policy Association

\section{Printed version}

Date of publication: 17 June 2019

Number of pages: 65-82

ISSN: 2679-3873

\section{Electronic reference}

Karl O'Connor, Saltanat Janenova and Colin Knox, «Open Government in Authoritarian Regimes », International Review of Public Policy [Online], 1:1 | 2019, Online since 17 June 2019, connection on 03 October 2019. URL : http://journals.openedition.org/irpp/325 ; DOI : 10.4000/irpp.325

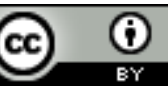

International Review of Public Policy is licensed under a Creative Commons Attribution 4.0 International. 


\section{Open government in authoritarian regimes}

\section{Karl O'Connor}

Ulster University

\section{Saltanat Janenova}

Nazarbayev University

\section{Colin Knox}

Nazarbayev University

\section{Abstract}

Open government has long been regarded as a pareto-efficient policy - after all, who could be against such compelling policy objectives as transparency, accountability, citizen engagement and integrity. This paper addresses why an authoritarian state would want to adopt a policy of open government, which may first seem counter-intuitive, and tracks its outworking by examining several facets of the policy in practice. The research uncovers evidence of insidious bureaucratic obstruction and an implementation deficit counter-posed with an outward-facing political agenda to gain international respectability. The result is 'half-open' government in which the more benign elements have been adopted but the vested interests of government and business elites remain largely unaffected.

\section{Keywords}

open government, Central Asia, administrative reform, bureaucracy, implementation, authoritarianism 


\section{Background}

Open government has been defined as 'the extent to which citizens can monitor and influence government processes through access to government information and decision making arenas' (Meijer et al, 2012: 11). In a practical sense, open government has long been promoted as a path to progressive development. The OECD, for example, sees it as 'a driver of inclusive growth' because it offers 'broad citizen participation, plurality and a system of checks and balances which, in turn, provide better access to services' (OECD, 2017: 42). Beyond the level of definition and principles that underpin open government, the literature is eclectic and tends to focus on individual components of the broader agenda. Hence there is research on: the social and economic value of opening (big) government data to the public, researchers, stakeholder's bodies, etc. (Janssen et al, 2012); the specific role which electronic government plays in the promotion of open government (Harrison et al, 2012); the role which social media can play in promoting greater openness, engagement and participation between government and citizens (Lee and Kwak, 2012); and, more direct forms of citizen engagement which move beyond the ICT components of open government (Evans and Campos, 2013).

The term 'open government' in the academic literature is most closely associated with freedom of information, anticorruption, and transparency (Nam, 2012). In the popular mind it is synonymous with former US President Obama's 2009 Open Government Directive, which focussed on how, via three principles, open government should work (Jetzek et al, 2013). First, using new technologies, government should be more transparent and provide information to citizens on what they are doing. Second, government should be participatory by engaging with citizens and, as a result, promote government effectiveness and improvement in the quality of the decision making process. Third, government should collaborate across all levels of government and with non-profits and business (Wirtz and Birkmeyer, 2015).

Open government is a new policy idea for authoritarian states and is now firmly on the policy agenda of Central Asia (Kazakhstan, Kyrgyzstan, Tajikistan, Turkmenistan and Uzbekistan). There is limited research on the composite role which open government might play in authoritarian states. There is, however, research on individual elements of open government, usually in single country studies (on e-government: Kneuer and Harnisch, 2016; Maerz, 2016; on citizen engagement: Kasymova, 2017; Denhardt et al, 2009; on civil society: Knox and Yessimova, 2015; and, on improving public services: Marat, 2016; Janenova and Suk Kim, 2016;), but no research on the overall impact of open government in authoritarian states.

As a result, this paper has three aims. First, with Kazakhstan as a case study, we pose the obvious question of why, given that authoritarianism and openness are seemingly incongruous, an authoritarian state would be interested in adopting open government. Second, we examine facets of open government in practice as a way of gaining insights into how it is operationalized and implemented on the ground. Finally, we attempt to explain the implementation gap between the strategic priority to promote open government and its outworking. We conclude with some wider reflections on open government in post-Soviet authoritarian states.

\section{Open Government in Central Asia}

Central Asian countries perform poorly on Open Government metrics (see Table 1). They are now being pressured by international donors, populist movements within their borders, and people agitating through social media to move from opaque to more open governance forms. Kazakhstan, in particular, has reached a stage of development where the population increas- 
ingly demands, through periodic civil unrest, more accountable and open government as a priority.

Table 1: Open Government Indicators - Central Asia (2019)

\begin{tabular}{|l|l|l|l|l|l|}
\hline Country & $\begin{array}{l}\text { Freedom } \\
\text { Status }\end{array}$ & $\begin{array}{l}\text { Political } \\
\text { rights }\end{array}$ & $\begin{array}{l}\text { Civil } \\
\text { liberties }\end{array}$ & $\begin{array}{l}\text { Freedom } \\
\text { rating }\end{array}$ & $\begin{array}{l}\text { Aggregate } \\
\text { score }\end{array}$ \\
\hline Denmark* & Free & 1 & 1 & 1.0 & 97 \\
\hline Kazakhstan & Not free & 7 & 5 & 6.0 & 22 \\
\hline Kyrgyzstan & Partly free & 5 & 4 & 4.5 & 38 \\
\hline Tajikistan & Not free & 7 & 6 & 6.5 & 9 \\
\hline Turkmenistan & Not free & 7 & 7 & 7.0 & 2 \\
\hline Uzbekistan & Not free & 7 & 6 & 6.5 & 9 \\
\hline
\end{tabular}

*Denmark is included here for the purposes of comparison only

Freedom status: average of a country's political rights and civil liberties. This score determines freedom status where: free $=1.0-2.5$; partly free $=3.0-5.0$; and, not free $=$ $5.5-7.0$

Political rights and civil liberties ratings: each rating is based on a scale of 1-7 where 1 represents the greatest degree of freedom and 7 the smallest degree of freedom.

Freedom rating: Countries and territories with a rating of 6 have very restricted political rights. They are ruled by authoritarian regimes, often with leaders or parties that originally took power by force and have been in office for decades. They may hold tightly controlled elections and grant a few political rights, such as some representation or autonomy for minority groups.

Countries and territories with a rating of 7 have few or no political rights because of severe government oppression, sometimes in combination with civil war. While some are draconian police states, others may lack an authoritative and functioning central government and suffer from extreme violence or rule by regional warlords.

Aggregate score: 100 is the highest aggregate score and 0 the lowest. 
Further, there is a strong central political imperative towards open government. Some Central Asian authoritarian leaders have issued top-down directives supportive of the principles of open government, fearful that their authority is being threatened through greater citizen awareness and mobilization. The increasing use of information technology and the spread of social media has seen citizens find channels to express their criticism of state practices. Autocratic rulers are frightened of colored revolutionary contagion associated with neighboring countries such as Georgia, Ukraine, Armenia, Belarus and Kyrgyzstan, and see a safer option to the status quo as to harness agitation through open government. Indeed, there are numerous examples of good open government practices emerging in some Central Asian countries. In Kazakhstan, for example, the introduction of e-government has been successful in minimizing transactional arrangements between officials and citizens, reducing corruption opportunities, and improving public services (Brimkulov and Baryktabasov, 2018). Moreover, World Bank indicators on government effectiveness, which include measurements of the quality of public services, testify to an improving situation (World Bank 2018). However, there are two points of note. First, open government as a reform initiative cannot be causally and exclusively linked to service improvements - other factors are at play. Civil servants receive better training, salaries are improving, and the introduction of public management has promoted a customer orientation. Second, open government in and of itself cannot move Central Asian countries classified as 'not free' to 'free'. Again there are other factors which will impact on such a shift, including wider political and constitutional changes. There has also been research on the potential of open data to boost public sector innovations in Kazakhstan and support the emergence of civic engagement initiatives (Kassen, 2017; Knox and Janenova, 2018). Similarly, Kyrgyzstan has witnessed an expansion of civil society and the growth of an independent media. It is the only Central Asia country to be categorized as 'partly free' because of its commitment to democracy and modestly competitive party politics, although not without evidence of vote buying in elections. Tajikistan shows evidence of an expansion in the number and range of NGOs as service providers. Civil society remains weak and is largely reliant on state funding and grants from international donors. The state remains authoritarian, clientelist and patriarchal under President Rahmon, who suppresses political opposition parties and appointed his son to the Office of Mayor of Dushanbe. The two least receptive countries to open government are Uzbekistan and Turkmenistan despite the former's mantra of 'from strong state to strong civil society'. Uzbekistan, for its part, has entered a new political era following the death of its first president (Islam Karimov) and the election of Shavkat Mirziyoyev, who has promised a range of political and economic reforms. This includes initiatives like a 'reach out to the people policy' intended to offer a more inclusive form of governance. Turkmenistan, on the other hand, has made no efforts to democratize and is essentially a closed country - it scores lowest on the freedom ratings of all Central Asian countries (see Table 1). The limited attempts which it has made to promote economic and political changes are aimed largely at the international community in an effort to attract foreign investment for industrial and infrastructure projects. In sum, the promotion of open Government has a patchy record across Central Asia. It has been embraced most strongly in Kazakhstan, to which we now turn.

\section{Case Selection}

We take the case of Kazakhstan to investigate the implementation of open government in practice. Kazakhstan is an example of the case of the most likely variety (Eckstein 1975) - if open government is likely to succeed in any Central Asian authoritarian regime, it is most likely to do so in Kazakhstan. The Republic of Kazakhstan is one of five Central Asian states that gained 
independence from the Soviet Union in 1991. It is the largest economy in the Central Asian region, having risen from a lower middle to upper middle-income country (GDP per capita, current $\$ 8,800$ ) in just two decades as a result of its large natural resources (oil, fossil fuels and precious metals such as uranium, of which it is the world's largest producer). This over reliance on natural resources and a fluctuating demand for oil means Kazakhstan has been attempting to diversify its economy. It has geo-political significance in that it links Chinese markets and South Asia, on the one hand, and Russia and Western Europe on the other. It will, for example, be part of the Chinese One Belt, One Road initiative that aims to connect Asia, Africa and Europe.

But why would an authoritarian regime want to adopt open government as a strategic priority? To wish to do so would seem counter-intuitive. However, Kazakhstan craves international respectability and, despite being an authoritarian state, it wants to be seen as a serious actor on the world stage. For example, it works closely with the OECD, spending large amounts of money on technical support from their experts with the ultimate aim of becoming an OECD member state. The OECD, in turn, has noted that Kazakhstan's government 'has expressed a strong interest in enhancing transparency, openness, accountability and participation in policy making in order to further develop public trust in government and improve the quality of public services' (OECD, 2017: 17). The first President (since Kazakhstan gained independence) has therefore promoted open government as a strategic priority in the Plan for the Nation (100 Concrete Steps), and part of a solution to ensure Kazakhstan is among the top thirty countries (measured by the Human Development Index) in the world by 2050. To do this, it needs, based on advice from the OECD, to enforce a root-and-branch reform process which includes embracing open government principles and practice (Knox, 2019). In an authoritarian regime where appointments are at the behest of the President, policy makers need to own the objectives of the regime. For example, The Minister for Information and Communication of the Republic of Kazakhstan, Dauren Abayev, stated:

Open government is a unique step of our state towards the democratization of society. Can you imagine that we will now be obliged to publish all budgets of the state bodies? Each of you can visit the official web-sites and see the budgets of the state bodies. Except for certain data, classified as "secret", all other data are open. (Mosunov, 2017).

Many of its formal public policies must 'read well' in the international arena. Kazakhstan is a member of the United Nations, the first Central Asian country to join, and was elected as non-permanent member of the UN Security Council (2017-18). Kazakhstan is also a member of the OSCE and it maintains cordial relations with the Islamic world and has chaired the Organization of Islamic Cooperation. It became a member of the WTO in 2015, hosted Expo 2017, a major world-wide future energy event, and has facilitated or mediated peace building talks on international conflicts (Russia and the Ukraine; Russia and Turkey; and Syria). All of these form part of an agenda of international approbation in which open government is an important element.

\section{Data Collection and Analysis}

So, if open government is a strategic priority for Kazakhstan, how has it been implemented on the ground? In order to structure the collection and analysis of data, we draw on a body of work conducted by the OECD (2016 \& 2017) on open government reforms which considers the principles of open government, policies to operationalize these principles, and their short- and long-term impact (see Table 2). We use this as an evaluative framework against which we as- 
sess the role played by bureaucrats in implementing open government. Hence, we interviewed participants in the research on the extent to which open government policies (set out in Table 2) were being successfully implemented in Kazakhstan and their role as officials therein.

Table 2: Operationalizing Open Government (OECD)

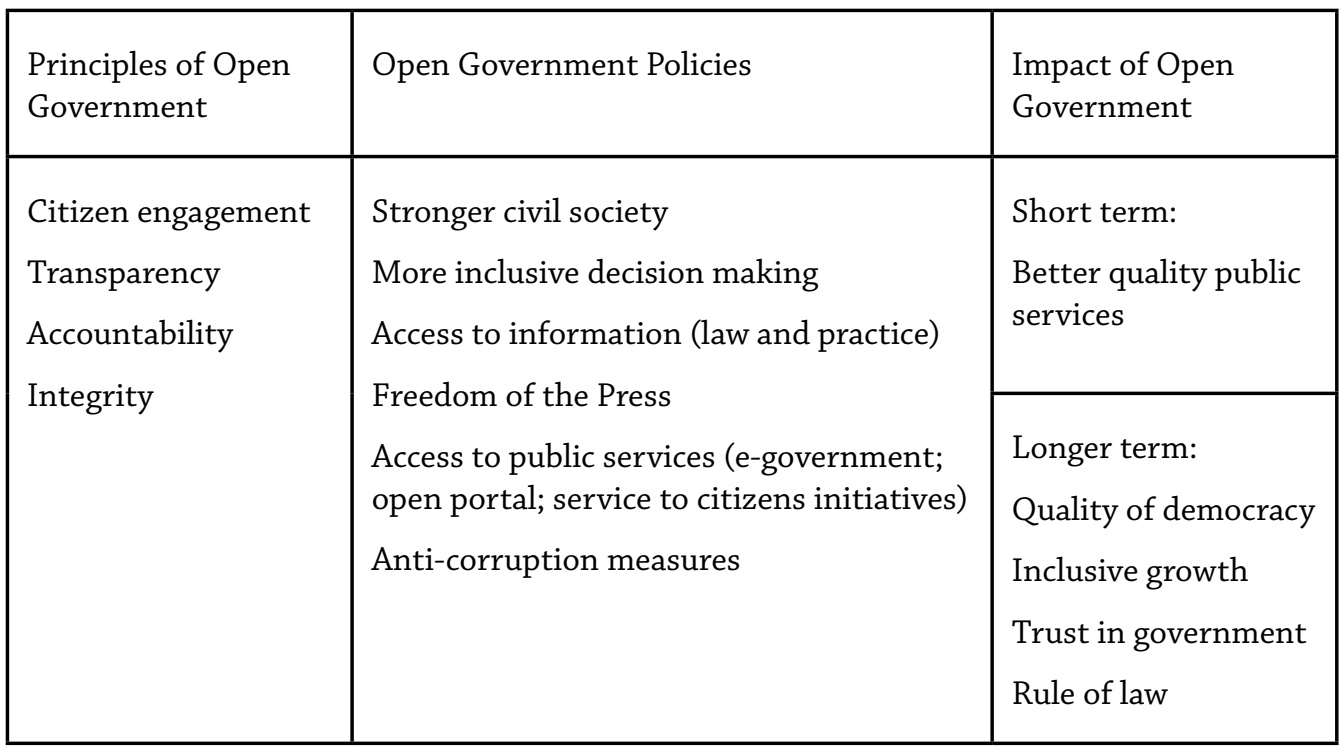

Source: The Authors

We draw on multiple sources of primary data to examine the implementation of open government in Kazakhstan.

(a) Senior Officials: two focus groups were conducted with government officials in Kazakhstan. The first group comprised Corpus A, or political elite civil servants holding the positions of general secretaries and vice-ministers, and Akims (appointed regional governors). Focus group participants were selected to reflect a range of political and official representatives across a range of ministries. This was a purposive sample with participants chosen because of their involvement in rolling out facets of open government. The first focus group took place at Nazarbayev University, Astana, Kazakhstan, in October 2017 and comprised 35 representatives, many more than the authors had actually anticipated. Attendance reflected both the convenience of the venue (all Ministries are located in Astana) as well as the political significance of the topic, with officials wanting to be openly interested in the President's policies. A second focus group took place in December 2017 at the General Prosecutor's office in Kazakhstan, a body known to be reformist and run by a dynamic leader. Twelve elite level bureaucrats were asked their views on the success of the open government agenda in Kazakhstan.

(b) Non-governmental organizations (NGOs): two further focus groups were held with NGO representatives and public councils in public buildings in one of the regional capitals. The purpose of public councils is 'the public expression of civil society views on matters of public concern' (Article 3 of the Law on Public Councils in Kazakhstan). The public council focus group ( $\mathrm{n}=18$ participants) was asked to identify their role and 
perceptions in terms of more inclusive decision making on the part of the government. The NGO focus group ( $\mathrm{n}=8$ participants) was asked about the role of civil society in Kazakhstan and whether this constituted greater receptivity and openness on the part of government to their views.

(c) Observation: In December 2017, the researchers observed a public meeting of a project entitled Open Canal (in Kazakh "Ashyk Arna"). The aims of this project are three-fold: to improve the level of public awareness on the instruments and mechanisms provided by the open government; to involve expert community and NGOs into the open government program and increase its demand; and to develop recommendations on improvement of public policy.

(d) Elite Interviews: Interviews were held with six regional Mayors and Deputy Mayors and fifteen directors and senior managers within the General Prosecutors Office (four from the Civil Service and Anti-Corruption Agency, and three from the Ministry for Civil Society and Religious Affairs). These interviews were conducted to gather primary data on access to public services and anti-corruption measures.

(e) Content analysis of legislation and the open government portal: Relevant legislation and accompanying news media were analyzed, coded by open government indicators and incorporated into the study. The open government portal in Kazakhstan (https://data.egov.kz) was analyzed in terms of its content, quality of information, and extent of use by citizens and government bodies.

Given the volume of data generated in two languages (Russian and Kazakh) and the high costs of translation, transcription into English was selective. The researchers used Excel's text data content analysis (sentiment analysis) with open government indicators as nodal points, and captured evaluative feedback on how the policy was being implemented in practice. Qualitative data analysis software such as NVivo is not available in the Russian language, and Kazakh was used intermittently during focus groups and interviews.

\section{Open Government Implementation}

We report on the implementation of open government under the headings in the OECD evaluative framework set out in Table 2 (column 2).

\section{Stronger Civil Society}

Kazakhstan has witnessed a rapid growth in NGOs. At their height, numbers exceeded 30,000, of which 18,000 were registered as NGOs (Knox and Yessimova, 2015). Today, however, only 8,300 NGOs remain active. State officials introduced a law entitled On State Social Order, Grants and Bonuses for NGOs (2015), which radically changed the relationship between the state and the NGO sector. Up until then, NGOs were able to access funding from a variety of donors: international organizations, private donations, by delivering public services and consultancy fees. The new law has significantly restricted access to funding other than from state sources through grants and competing for 'social orders' (delivery of public/social services) on a competitive basis. Bureaucrats justified this clamp-down on foreign grants because of what they described as corruption amongst NGO leaders and a lack of transparency and accountability in spending foreign donor monies. The leader of one prominent NGO commented on this as follows:

In the past NGOs received foreign funding from different international organizations. We 


\begin{abstract}
had several cases when heads of the NGOs misused grant funding for their personal interests rather than public interests. I think this law on grants to the NGOs has changed the situation when only active NGOs, those who can demonstrate through their performance and results, are getting social grants. The rest will disappear.
\end{abstract}

All NGO funding, government and international donors, is now channelled through a joint stock company called Centre for Support of Civic Initiatives, which is controlled by officials in the Ministry for Religious Affairs and Civil Society. NGOs must be registered on the Ministry's electronic database to become eligible for state funding and entitled to receive state bonuses awarded to those NGOs which have successfully implemented social projects.

The new law on civil society also exerts bureaucratic control on the type of NGOs and spheres of activities deemed to be appropriate for the development of Kazakhstan. Hence Article 5 of the law stipulates the provision of state social orders, grants and bonuses in the areas of: education and science; physical culture and sports; healthy lifestyle; environmental protection; support for the youth and children's projects; support for vulnerable groups and the unemployed; protection of historical cultural heritage; and strengthening national unity. All of these are seemingly worthy causes but rather benign; conspicuous by their absence are NGOs active on issues of public participation in policy-making, promoting government accountability and transparency, fighting corruption, and human rights.

The leader of a local NGO shared his concerns in the following way:

As we have to apply for state funding, we are no longer independent. We cannot be considered as 'non-governmental organizations', we are pro-governmental as the only source of finance is the government. I doubt that corruption is now less with the funding regime for the NGOs. Decisions and power on allocation of funding is now in the hands of the Ministry.

Consequently, while NGOs willingly accept there had been a limited number of cases of corruption and misuse of funding in the third sector, they accuse officials of intentionally perverting the open government agenda in order to: exert exclusive control over their funding; dictate the benign priority public policy areas in which they can be active; and place them in an invidious position which muzzles any hint of independent criticism of public services provision.

\title{
More Inclusive Decision-Making
}

Three main policies have been adopted by the Kazakhstan Government to promote greater citizen inclusion in the decision making process: the open government portal; open dialogue; and open budgets. The open government portal provides an opportunity for citizens to participate in the discussion of drafts of normative legal acts through the platform Open Legislation (https://legalacts.egov.kz/). It was designed to ensure the accessibility of draft legislation to stakeholders and the general public. At the time of writing (February 2019) over 15,000 drafts of legal acts have been posted on this platform, an indication of the highly legalized framework through which officials implement public policies. Yet this voluminous legal repository on the open government portal has attracted only 415 posts. It would be easy to conclude that the turgid nature of legalese on this portal is a turn-off for the average citizen, except that a number of the policies to which the legislation refers have resulted in a public outcry via social media networks. For example, 2013's draft Pension Law, which increased the retirement age of women from 58 to 63, witnessed heated debates on social media (Maltseva and Janenova, 2019). The new amendment to the land code in 2016 on long-term leasing of agricultural land to foreign countries even sparked significant protests from a mobilized public, leading to the 
code eventually being postponed (Bacchi, 2016). Citizen registration was introduced into law in January 2017, placing a responsibility on property owners to register people residing in their houses, ostensibly to combat extremism. Citizens must now register with local authorities if they move within the country and remain in one locality for more than a month. One well-known lawyer, Dzhokhar Utebekov, compared the new rules to 'serfdom' and claimed that it was designed with greater monitoring and control of citizens in mind (Omirgazy, 2017:1).

Another component of the open government portal is Open Dialogue (https://dialog.egov. $\mathrm{kz} /$ ), the aim of which is to encourage a dialogue between the citizen and the state. The main goal of the portal is 'to involve citizens in the activities of state bodies'. Users can directly submit an appeal and send proposals to a specific state body or local akimat, report on the quality of the mobile cell network, and participate in social surveys. The on-line nature of this provision is intended to facilitate citizens' inputs across the huge geographical area of Kazakhstan, avoid queuing to access basic information on public services, and raise awareness of compliance issues amongst the population. Open Dialogue offers three main services: blog-platforms of the heads of the central and local government bodies; internet conferences; and survey polls. Compared to participation in Open Legislation, citizens have expressed a much higher interest and activity in writing on the blogs of ministers and mayors (Akims). Each blog is coordinated by a moderator from the relevant state body, and the comments and questions of the citizens may or may not appear on these blogs, which is subject to approval by the state moderator. The language of communication from the government side remains highly bureaucratic and impenetrable to the average citizen. One focus group participant described it as follows:

Open Dialogue has good intentions but its effectiveness often depends on the personalities of ministers or Akims and the gate-keeping role of site moderators. Even for active state representatives, it can be a publicity tool to boost their image for political progression.

The Open Budgets portal (https://budget.egov.kz/) was created to promote citizen inputs, monitoring and feedback on how public bodies spend budget funds. The law of the Republic of Kazakhstan On Access to Information (16 November 2015 No.401-V) introduced new responsibilities to government bodies to publish their budgets on web-sites (Article 16). The Open Budgets portal should publish draft budget programs before they are approved, giving people the opportunity to participate in an open discussion on the draft budget. However, these legal requirements are not implemented in practice. The government bodies either do not publish budget information or publish them in an unfriendly format which is difficult for citizens to access and understand (Moldabekov, 2016). According to the Open Budget Survey 2017, Kazakhstan received ${ }^{1}$ :

- A score of 53 score out of 100 in terms of transparency (Open Budgets Index) and was deemed to 'provide the public with limited budget information'.

- A score of 13 score out of 100 for public participation in budget planning, therefore '[providing] few opportunities for the public to engage in the budget process'.

- A score of 63 score out of 100 for budget oversight by legislature and audit, indicating that 'the legislature and supreme audit institution in Kazakhstan provide adequate oversight of the budget'.

The head of the NGO Centre for Support of Legal and Economic Reforms commented in this regard:

1 - Source : International Budget Partnership, 2017 


\begin{abstract}
Not all Akimats (Mayors) publish annual reports on the execution of the region's budget. Now the draft annual budget execution report for 2016 is only posted on the website of the Akimat of East Kazakhstan region. Eleven out of sixteen Akimats did not publish even the accounts for 2015 (Gareyeva, 2017:2).
\end{abstract}

In summary, while bureaucrats can point to a number of fora for more inclusive decision making, the inaccessible legalese that constitutes the open legislation portal, the gatekeeping role exercised by officials in the open dialogue platform, and the lack of compliance in open budgeting, respectively, amount to tacit resistance to the principles of open government.

\title{
Access to Information (Law and Practice)
}

The Law on Access to Information (2015) stipulates the rights of journalists to receive information from the government through oral or written/emailed requests. In practice, this norm is ignored or frustrated as government bodies demand journalists' requests to be on official paper and delay providing answers. Focus group participants have highlighted several problems related to accessing information, including low level of responsibility of the government bodies to involve the public and limited participation by citizens. As the representative of the Ministry for Information and Communication described:

There are cases when state bodies simply do not respond to the proposals of the population or respond illiterately. Our ministry is working on this and, in particular, the requirements for assessing the effectiveness of state bodies with regard to their involvement of the public will be increased.

A representative from the 'Open Canal' project noted that the Law on Access to Information was neither informative nor comprehensible for ordinary citizens. He commented:

\begin{abstract}
This law is just about access to information, which is primarily addressed to the public, so that people, after reading the law, can understand how you can get this information from any government body. But the law does not work because there are many formal reasons for refusal. Procedures are unclear on: how the drafts of normative acts should be published; how they should be discussed; and what rights citizens have.
\end{abstract}

The deputy of the Parliament as a key speaker at the 'Open Canal' meeting expressed his disappointment: 'The state bodies of Kazakhstan do not respond willingly to the calls of citizens, not to mention the execution of the Law On Access to Information'. In short, bureaucrats frustrate both the spirit and letter of the law on access to information through delays on time-sensitive issues or draw on a host of reasons for refusing access. They play a role of passive non-compliance and hide behind convoluted legal terminology in the Act to justify non-disclosure.

\section{Freedom of the Press}

Recent amendments to the law of the Republic of Kazakhstan, 'On Mass Media', adopted in December 2017, risk limiting civic participation and creating a repressive rather than an open government culture. Article 21, for example, obliges journalists to receive consent from any legal person to disseminate personal, family, medical, banking, commercial and other sensitive information in the media. Under these terms, any unethical and corrupt behavior of civil servants can be potentially hidden. Journalists require the permission of officials to report unethical conduct, which may include: holidays in expensive resorts around the world, family members of officials possessing luxury apartments and expensive cars, and transfer of large funds to personal accounts in foreign banks. Specifically, the new legislative norms restrict the rights of journalists and citizens to freedom of information about the actions and conduct of government officials. In the event of a breach of these rules, owners of the mass media out- 
lets, chief editors, journalists and authors of materials will be held responsible by the criminal court. As one journalist asked rhetorically:

The situation is ludicrous. Do you think as a journalist I am going to receive advance permission from an official to report on his/her extravagant lifestyle which appears inconsistent with his/her earnings?

Repressive measures have increased against independent media outlets. For example, criminal investigations were conducted in spring 2018 on two prominent media outlets, Ratel.kz and Forbes Kazakhstan. Citizens have therefore found their voice through social media. One research participant noted:

In the absence of press freedom, social media has filled the vacuum. At first officials did not know how to respond. They were like rabbits caught in headlights (in Russian: как запуганный зверь). As 'press freedom' heralded greater restrictions on journalists, social media activity increased. Now state officials are finding ways to control its spread and influence.

As the power of social media has become a threat to the political and bureaucratic elite, they have found new ways to control it. New legislative amendments were enacted in January 2018 to prohibit the anonymity of bloggers and social network commentators. The government legitimizes these changes as a response to terrorism and extremism intended to protect the public. Kazakhstani citizens are able to post a comment on any news or media articles only after authorization through a digital signature or SMS-message.

\section{Access to Public Services}

The government's tendency to monopolize and centralize state control has been demonstrated in public service provision. In 2016 a new State Corporation, Government for Citizens, was established to provide all public services. Based on Canada's Service First and Australia's Centrelink initiatives, the State Corporation delivers over 700 public services on behalf of government bodies and public sector organizations through multiple channels: over 300 Public Service Centers (or One Stop Shops); an e-government portal (http://egov.kz/); and free phone call-centres. The so-called Situational Centre was introduced in 2012 to monitor and observe the actions and operations of all employees (over 10,000) working in the public service centres and call-centres. The system has cameras with video and audio recording facilities, providing information on a daily basis from the regions to the central office in Astana. This allows central-level managers to monitor statistics on the number of customers waiting in the queue, the number of processed documents, and the number of complaints in the online system. The Situational Centre also allows officials to listen to the conversations from any of the public service centres, for example exchanges between a client and a front-line employee, or between managers and subordinates.

The senior manager of the State Corporation explains the benefits of this system in the following way:

The Situational Centre helps us to conduct monitoring over the quality of public service delivery in an effective way. It allows us to identify problems, for example, there is a long queue in the remote regional public service centre...so we are able to track and address these situations immediately, and punish those employees who are not disciplined, impolite or miss deadlines of documents review.

The focus of these interventions has been on monitoring the performance and behavior of employees - employees do the same jobs as before, yet the state uses technology to monitor 
their actions.

A similar example relates to new legislative measures introduced in December 2016 requiring citizens to register at their place of residence (Legislative Acts on Countering Extremism and Terrorism). The main objective of registering citizens was to monitor the flow of internal migration and, in response, plan public services to meet changing population needs in education, employment, medical care and so on. The secondary purpose was to enhance security and reduce risks of terrorism. This led to a significant increase in migration police and home 'inspections'. Human rights activists have raised concerns about corruption amongst migration police, particularly against vulnerable and disadvantaged migrants. As one research participant noted:

The whole citizen registration process has been a ruse. What began as a legitimate reason for its introduction, planning better public services and citizens protection, has turned into a mechanism to track people's movements and activities. No wonder trust in government intentions is low. Officials pretend to do one thing but have malign intentions. It is all about monitoring and control.

\section{Anti-Corruption Measures}

Kazakhstan, like other Central Asian countries, is dogged by corruption despite a raft of legislative measures which have been put in place and several high profile criminal convictions of senior officials and government ministers. As part of a wider preventative strategy and to acknowledge that corruption is rife amongst certain ministries, in January 2016 the Kazakhstan government introduced an ethics code, to be enforced by newly appointed ethics commissioners, with the aim of raising standards in public life. The commissioners' primary responsibility under the new law was to ensure 'compliance of civil servants with the legislation in the areas of civil service, anti-corruption and the code of ethics'. This initiative received strong political endorsement from the President of Kazakhstan. Yet the reality of their work has been somewhat different. Commissioners have been appointed from within the existing ranks of officials and their roles are highly circumscribed by superiors, many of whom do not want cases of unethical behavior or corruption exposed in their ministries. As one research participant pointed out:

The management will not allow big scandals and violations to leak out. Even if an ethics commissioner raises an ethical offense, top management can close down this topic at the beginning. So, many civil servants do not complain because they do not believe at the outset that the problem will be solved.

The job of commissioners has also been denigrated to one of whistle-blowers in a system where loyalty and patronage are highly valued. Instead, senior managers use commissioners to diffuse personnel issues in their ministries.

\section{Discussion}

What, then, explains the gap between the strategic priority of the President in promoting open government in Kazakhstan and its outworking as evidenced by the above qualitative data? We suggest two key explanatory causes: bureaucratic obstruction and an implementation deficit, detailed in the following discussion.

\section{Bureaucratic obstruction}

There are three key factors which explain how Kazakh officials subvert the strategic priorities of the state. First, in circumstances where there is a low degree of political trust amongst the population, there is likely to be a high degree of administrative power. In Kazakhstan, people 
do not trust the political system but place unstinting trust in the President. Equally, as a society, Kazakhs have strong family values and place less reliance on the role of government. Peters (2018: 66) describes these circumstances as:

The population is less willing to accept the decrees of government than the needs of the family or the guidance of the local patron. In these cases, the bureaucracy may be required to step in to fill a power vacuum in the political system.

Second, the near monopoly hold on political power by the President's political party (Nur Otan) and its influence on the bureaucracy makes civil service neutrality impossible. Citizens complain about poor public services to Nur Otan rather than to bureaucrats. Third, the confluence of strong institutions (bureaucracy and political party) and their combined interests in maintaining opaque government makes their capacity to subvert strategic Presidential priorities strong.

At the highest levels of the government, ministers and Akims are appointed by the President and senior officials are also key figures in a largely one party (Nur Otan) state, even though, tokenistically, smaller political parties exist. Ministers are frequently reshuffled and during this process bring with them a cadre of 'loyal' officials who have earned their trust. This governance system means that the civil service is highly politicized, including the appointment of a number of political civil servants whose role is to ensure party policy is enforced. The boundaries between senior officials in the President's political party, ministerial and Akims appointments, political civil servants and the senior officials (Corps A civil servants) are seamless. There is a free transfer market between these elites, despite the charade of merit-based recruitment to Corps A officials. In that sense, it seems counter-intuitive that the wishes of the President on open-government could be subverted by the ministers and civil servants either directly appointed or selected through a 'merit-based' system. However, this fails to recognize the power of the political, official and business elites in Kazakhstan whose interests would be undermined by greater openness. A stronger civil society offers an alternative voice for citizen complaints, open budgeting provides opportunities to challenge resource distribution, access to information may uncover evidence to confront government decisions and highlight corrupt practices in areas like public procurement, bribery and rent seeking. So, while the virtues of having a political civil service in some Western societies are promoted as ways to ensure the electoral mandates of politicians are faithfully implemented (Peters and Pierre, 2004), in postSoviet societies this arrangement may provide a bulwark to protect political and administrative elites rather than as a means of implementing strategic priorities which they see as threatening the status quo.

While there is overt bureaucratic obstruction at the senior echelons of the civil service, midcareer officials tacitly resist for several reasons. The volatility of the system at the top means that the public policy context in which they exist is in a constant state of flux and stated policies are rarely implemented, still less evaluated. As a result, there is no institutional memory on which to build on successes or learn from failures. The middle tier of the civil service also lacks capacity, is poorly paid, works long and unproductive hours and, by its nature, resists change to the bureaucratic process (Janenova and Knox, 2018). Mid-tier civil servants operate in a system that punishes failure and prefers the comfort of pre-existing procedures and processes. Changing to an open government culture would represent a major cultural shift, taking risks, and affirmative signals from the top that changes were sanctioned. Without this, there is systemic but tacit resistance to open government. Overall, Peters (2018: 224) describes these circumstances as the dual hierarchy of party and bureaucracy, which 'can be used to ensure the 
compliance and control of the civil service' in two ways: firstly, the party provides ideological guidance which the civil service internalizes; and second, the party acts as a check on the performance of the officials who may deviate from the ideology of opaque government.

Aside from the porous boundaries between political party and the state bureaucracy, the association with key business interests also plays a part. Peters (2018) refers to this as a 'parantela relationship' involving kinship ties between the business sector as a pressure group and political parties that advocates their interests in the bureaucracy. He describes this as pressure groups 'developing some feeling of consanguinity' with the political party that indirectly gives them significant policy influence in the civil service (Peters, 2018: 183). Open government is unlikely to serve the interests of these pressure groups.

\section{Implementation deficit}

Given the sheer size of Kazakhstan and its low population density, realizing open government poses significant implementation problems. Although Kazakhstan has a highly centralized system of governance, regional Akims, as Presidential appointees, wield significant power. Their distance from the centre of government might suggest greater local influence to comply with strategic priorities and some policy discretion in so doing. However, Akims represent both the interests of the bureaucracy and the political party at the regional level. Hence, they 'conspire' to create an implementation deficit in the President's strategic priority for open government, a situation in which passive citizens who may not fully realize its potential unwittingly acquiesce.

Implementation is also affected by policy ambiguity. Open government as a concept is poorly understood. The OECD framework, which we use in this paper to operationalize the principles of open government, is multi-faceted and could give rise to principal-agent problems. To what extent will senior officials be motivated, for example, to actively implement anti-corruption measures when they are complicit in practice? Moreover, do all the policies outlined in the framework (civil society, more inclusive decision making, access to information, freedom of the press, and anti-corruption measures) contribute equally to securing open government? This makes open government an ambiguous policy.

Matland's analysis (1995) of the impact of conflict and ambiguity on policy implementation is useful in conceptualizing the failure of open government in Kazakhstan. Matland suggests a matrix comprising two dimensions of policy (see Table 3), one indicating a high/low degree of ambiguity and, as a consequence, offering room for high/low discretion in implementation, respectively. Ambiguity tends to make discretion more likely. The second dimension is the extent to which a policy provokes conflict. The degree of conflict will depend on whether there are very explicit and clear losers should the policy be implemented.

\begin{tabular}{|l|l|l|}
\hline \multicolumn{3}{|c|}{ Table 3: Impact of conflict and ambiguity upon implementation } \\
Adapted from Matland's Analysis (1995) \\
\hline & Low Conflict & High Conflict \\
\hline Low Ambiguity & Administrative Implementation & Political Implementation \\
\hline High Ambiguity & Experimental Implementation & $\begin{array}{l}\text { Symbolic Implementation: } \\
\text { Open Government in Central Asia }\end{array}$ \\
\hline
\end{tabular}


Conflict, according to Hill (2013: 217) 'implies a desire to control. Actors claiming hierarchical rights will seek to assert them'. Hence an open government policy may be an agreed strategic priority for Kazakhstan but one which includes greater press freedom and could therefore expose the excesses of bureaucrats and politicians, generating a potentially high conflict policy. Matland argued that with high ambiguity, high conflict policies will result in 'symbolic implementation' where no effort is expended in giving real effect to a policy. But officials and politicians, in the case of open government, may simply want to claim to the President and international organizations that they have tried.

One of the outcomes of policies which are characterized as 'high ambiguity-high conflict' is that local level coalitional strength determines outcomes. How the policy is implemented is determined, according to Matland, by the coalition of stakeholders at the local level who have direct influence over resource allocation. There may be competing coalitions who contest different interpretations of an open government policy that is ambiguous. As Matland argued: 'When a policy has a referent goal and ambiguous means...the coalitional strength at the micro level, not at the macro level, determines the implementation outcome' (Matland, 1995: 170). In the case of open government, coalitions of interest comprising local level Akims, bureaucrats, and the business elite conspire to thwart implementation.

Additional factors that influence implementation of open government, drawing on the conceptual framework developed by Van Meter and Van Horn (1975) and refined by Hill (2013), include the following:

- Policy characteristics: open government may be seen as a Western model that fails to acknowledge the legacy of Soviet history on independent states like Kazakhstan. Opaque and unresponsive government are the norm.

- Layers in the policy transfer process: Kazakhstan has a huge public sector with multiple state agencies, arms-length, state-owned enterprises and an underdeveloped private sector. Policy implementation in this diffuse structural morass will always prove difficult.

- Horizontal inter-organization relationships: ministerial fiefdoms are carefully guarded as they can dictate the fate of political careers and discourage cross-cutting policy issues such as open government. Government is vertical and ministers are most interested in attracting the favorable attention of the President.

- Factors affecting responses by implementing agencies: there are few politicians or senior bureaucrats championing open government as a strategic priority, still less street level workers, who find the concept highly ambiguous and its relevance for the daily lives of Kazakhstani citizens tangential.

- Responses from those affected by the policy: the most obvious manifestation in a practical sense for citizens of Kazakhstan is access to public services through electronic government. Other facets of open government are too abstract in their hierarchy of needs.

- Wider macro-environmental factors: politicians and senior bureaucrats buy into the concept of symbolic implementation in their collective quest for the international approbation of Kazakhstan and its goal of becoming one of the top thirty developed countries by 2050 .

We summarize these two explanations for 'open-government' in Kazakhstan in Figure 1. 
Figure 1: Half-Open Government in Kazakhstan

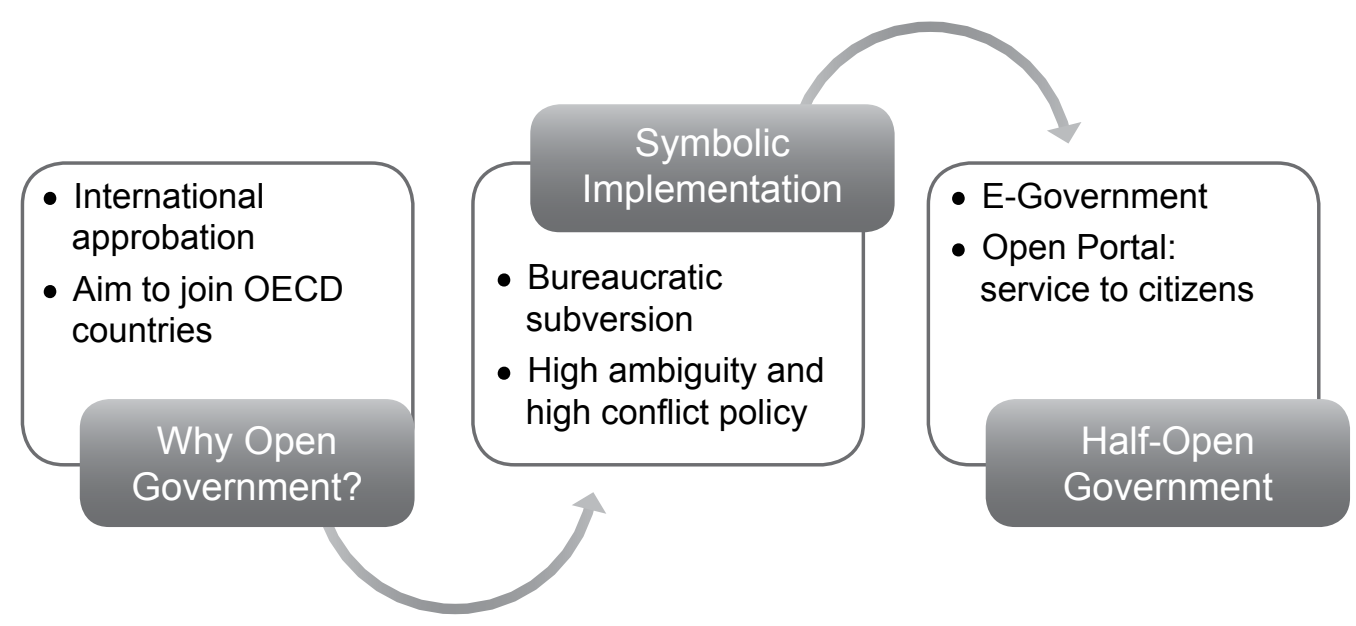

Source: The Authors

\section{Conclusion}

We conclude that the government of Kazakhstan was never truly committed to the merits of open government and hence is engaging in this agenda for the purposes of international optics, consistent with their declared intentions to become one of the top thirty developed countries by 2050 . This being the case, why would bureaucrats bother to develop various laws and policy instruments to actualize open government if their intentions were merely symbolic implementation? It may be that they began with a genuine desire to implement the will of the President on open government but when they realized how its full import would threaten their interests, they thwarted its implementation. Open government is now perceived as a threat to the bureaucratic elite, who have subverted attempts to make their actions transparent and their activities accountable. The outworking of open government alarmed bureaucrats, who thus reverted to a command, control and punish mentality inherited from their Soviet roots. This alarm has several causes: bureaucrats witnessed bottom-up social unrest and feared a color revolution (contagion from neighboring countries); their power-base was being scrutinized and challenged, including their personal lifestyles and behaviors; and they were uncomfortable or not used to listening to the views of, and having to respond to, a public transitioning from being passive to active citizens. More generally, change can be threatening. When that change is, in part, motivated by Western-inspired principles (isomorphic mimicry), bureaucrats reverted to type - stronger control and monitoring, a comfort zone in which they are well versed. Comparing Central Asian countries on their open government performance may seem like measuring developing countries with very different political ideologies against Western liberal democratic standards. In the case of Kazakhstan, however, its self-declared strategic goal, to become one of the top thirty developed countries, makes such a comparison reasonable. If this example of embracing open government is true of Kazakhstan, then other Central Asian countries, some with more repressive regimes, may well experience similar problems. Open government in Kazakhstan may have been the President's intention; bureaucratic obstruction, symbolic implementation and half-open government is the reality. 


\section{Bibliography}

Bacchi, U. (2016). Campaigners Urge Kazakhstan to Free Activists Facing Trial Over Land Reform Protests. Reuters, 12 October. https://www.reuters.com/article/us-kazakhstan-landrights-trialidUSKCN12C035

Brimkulov U., Baryktabasov K. (2018). E-Government Development in the Central Asian States: Best Practices, Challenges and Lessons Learned in: Alcaide Muñoz L., Rodríguez Bolívar M. (eds), International E-Government Development. London: Palgrave Macmillan. 121-154

Denhardt, J., Terry, L., Delacruz, E.R. and Andonoska, L. (2009). Barriers to Citizen Engagement in Developing Countries, International Journal of Public Administration, 32(14), 1268-1288.

Eckstein, H. (1975). Case Studies and Theory in Political Science. In. Greenstein F.I \& Polsby N.W. (eds.), Handbook of Political Science. Political Science: Scope and Theory (7) Reading, MA: AddisonWesley. 94-137.

Evans, A.M. and Campos, A. (2013). Open Government Initiatives: Challenges of Citizen Participation. Journal of Policy Analysis and Management,32(1), 172-185.

Freedom House (2019). Freedom in the World. Accessible at: https://freedomhouse.org/report/freedom-world/freedom-world-2019

Gareyeva, M. (2017). State Bodies do not Understand Why They Publish Budget Data, Informburo. 11 May, https://informburo.kz/novosti/gosorgany-ne-ponimayut-zachem-publikuyut-byudzhetnye-dannye-obshchestvenniki.html

Harrison, T.M., Guerrero, S., Burke, G.B., Cook, M., Cresswell, A., Helbig, N., Hrdinová, J. and Pardo, T. (2012). Open Government and E-government: Democratic Challenges From a Public Value Perspective. Information Polity, 17(2), 83-97.

Hill, M. (2013). The Public Policy Process. London: Pearson Press (6th ed.)

International Budget Partnership, Open Budget Survey (2017). Kazakhstan, accessible at: https:// www.internationalbudget.org/open-budget-survey/results-by-country/country-info/?country=kz

Janenova, S. \& Kim.P.S. (2016). Innovating Public Service Delivery in Transitional Countries: The Case of One Stop Shops in Kazakhstan. International Journal of Public Administration, 39 (4), 323333.

Janenova, S. \& Knox, C. (2018). Civil Service Reform in Kazakhstan: Trajectory to the 30 Most Developed Countries? International Review of Administrative Sciences. https://doi. org/10.1177/0020852317722397

Janssen, M., Charalabidis, Y. \& Zuiderwijk, A. (2012). Benefits, Adoption Barriers and Myths of Open Data and Open Government. Information systems management, 29(4), 258-268.

Jetzek, T., Avital, M., Bjorn-Andersen, N., (2013). The Generative Mechanisms of Open Government Data. Atlanta, GA: AISeL.

Kassen, M. (2017). Open data in Kazakhstan: incentives, implementation and challenges, Information Technology \& People, 30(2), 301-323.

Kasymova, J. (2017). Understanding the Challenges and Sustainability of Citizen Engagement in the Budgeting Processes of Developing Countries. Administration and Society, 49 (3): 374-393. 
Kneuer, M. and Harnisch, S. (2016). Diffusion of E-government and E-participation in Democracies and Autocracies. Global Policy, 7(4), 548-556.

Knox, C. (2019). Public Sector Reform in Central Asia and the Caucasus. International Journal of Public Administration, 42(2), 168-178.

Knox, C. and Yessimova, S. (2015). State-Society Relations: Non-Government Organisations in Kazakhstan. Journal of Civil Society, 11 (3), 300-316.

Knox, C. and Janenova, S. (2018) 'Public Councils in Kazakhstan: a Case of Emergent Participative Democracy?. Central Asian Survey 37 (2), 305-321.

Lee, G. and Kwak, Y.H. (2012). An Open Government Maturity Model for Social Media-Based Public Engagement. Government Information Quarterly, 29 (4): 492-503.

Maerz, S.F. (2016). The Electronic Face of Authoritarianism: E-government as a Tool for Gaining Legitimacy in Competitive and Non-Competitive Regimes. Government Information Quarterly, 33(4), 727-735.

Maltseva, E. \& Janenova, S. (2019). The Politics of Pension Reforms in Kazakhstan: Pressures for Change and Reform Strategies, in An, S., Chubarova, T., Deacon, B., Stubbs, P. (eds). Social Policy, Poverty and Inequality in Central and Eastern Europe and The Former Soviet Union. London, UK: JH Publishing,

Marat, E. (2016). Reforming police in post-communist countries: international efforts, domestic heroes. Comparative Politics, 48 (3), 333-352.

Matland, R.E. (1995). Synthesizing the Implementation Literature: the Ambiguity-Conflict Model of Policy Implementation. Journal of Public Administration Research and Theory, 5 (2), 145-174.

Moldabekov, D. (2016). State Bodies do Not Implement the Law “On Access to Information", Kapital, 15 February, https://kapital.kz/gosudarstvo/47880/gosorgany-ne-soblyudayut-zakon-odostupe-k-informacii.html

Mosunov, I. (2017). What opportunities does Open Government provide?. Informburo, 28 July, https://informburo.kz/stati/kakie-vozmozhnosti-dayot-otkrytoe-pravitelstvo-dlya-grazhdan-.html

Nam, T. (2012). Citizens' Attitudes Toward Open Government and Government 2.0. International Review of Administrative Sciences, 78(2), 346-368.

OECD (2016). Open Government: the Global Context and the Way Forward. Paris OECD.

OECD (2017). Towards Effective Open Government Reforms in Kazakhstan. Paris: OECD Governance Review.

Omirgazy, D. (2017). Citizens' Registration Law Draws Controversy and Confusion. Astana Times, 23rd January.

Peters, B.G. \& Pierre, J, (2004). Politicization of the Civil Service: The Quest for Control. London: Routledge.

Peters, B.G. (2018). The Politics of Bureaucracy: an Introduction to Comparative Public Administration. London: Routledge.

Van Meter, D, and Van Horn, C.E. (1975). The Policy Implementation Process: a conceptual framework. Administration and Society, 6 (4): 445-488.

Wirtz, B.W. and Birkmeyer, S. (2015). Open government: origin, development, and conceptual perspectives. International Journal of Public Administration, 38 (5): 381-396. 